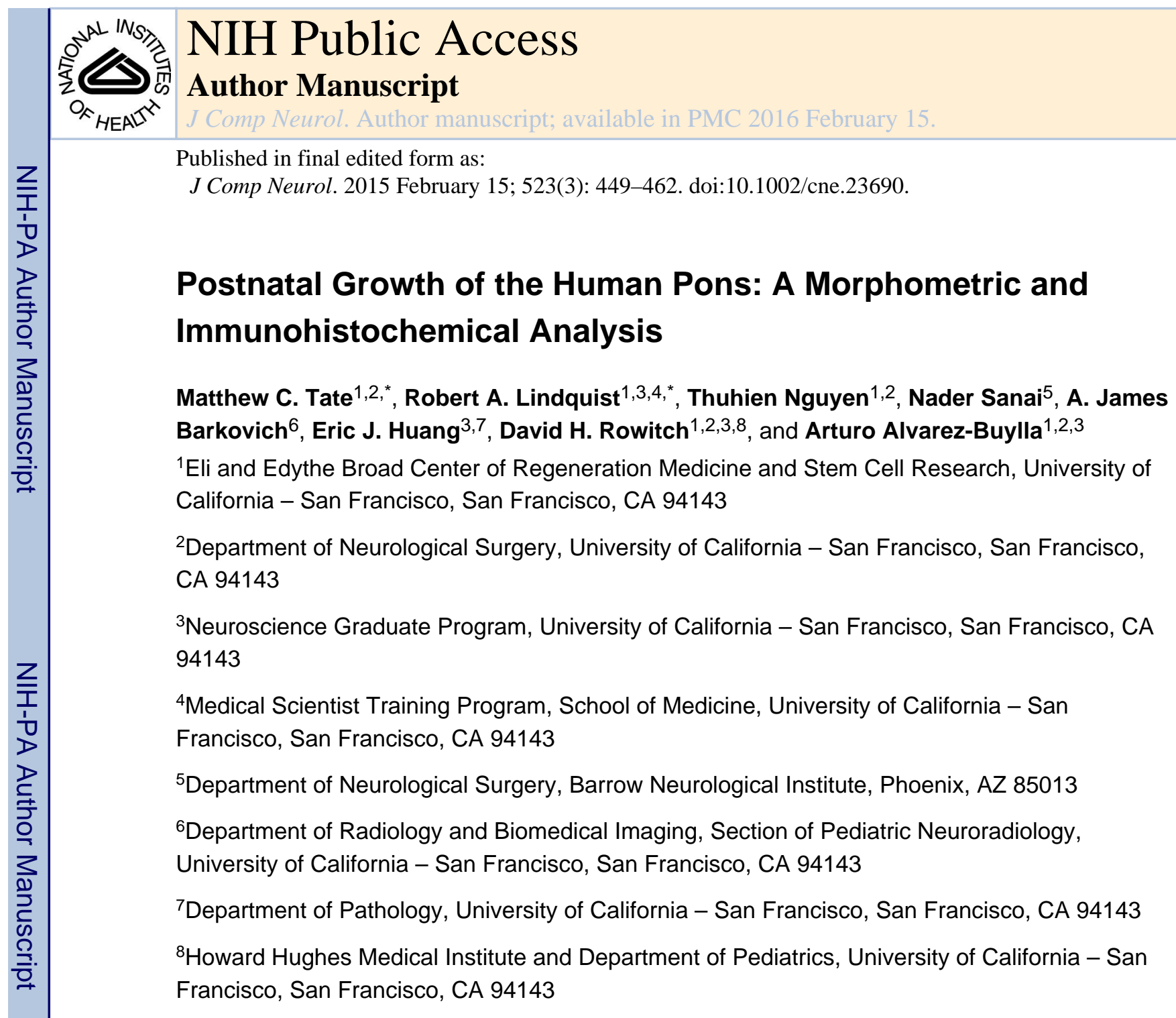

\title{
Abstract
}

Despite its critical importance to global brain function, the postnatal development of the human pons remains poorly understood. In the present study, we first performed MRI-based morphometric analyses of the postnatal human pons ( $0-18$ years; $n=6-14 /$ timepoint). Pons volume increased 6-fold from birth to 5 years, followed by continued slower growth throughout childhood. The observed growth was primarily due to expansion of the basis pontis. T2-based MRI analysis suggests that this growth is linked to increased myelination, and histological analysis of myelin basic protein in human postmortem specimens confirmed a dramatic increase in myelination

Corresponding Author: Arturo Alvarez-Buylla PhD, University of California, San Francisco, Department of Neurological Surgery, 35 Medical Center Way RMB-1038, Box 0525, San Francisco, CA 94143-0525, Phone: 415-514-2348, Fax: 415-514-2346, abuylla@stemcell.ucsf.edu.

*Authors contributed equally to this work

CONFLICT OF INTEREST

The authors report no conflicts of interest.

\section{ROLE OF AUTHORS}

All authors had full access to all the data in the study and take responsibility for the integrity of the data and the accuracy of the data analysis. Study concept and design: MT, RL, NS, DR, AA-B. Acquisition of data: MT, RL, TN, AB. Analysis and interpretation of data: MT, RL, TN, AB, EH, DR, AA-B. Drafting of the manuscript: MT, RL, TN. Critical revision of the manuscript for important intellectual content: MT, RL, TN, NS, AB, EH, DR, AA-B. Statistical analysis: MT, RL. Obtained funding: MT, EH, DR, AA-B.

Administrative, technical, and material support: MT, RL, TN, EH. Study supervision: AA-B, DR. 
during infancy. Analysis of cellular proliferation revealed many Ki67 ${ }^{+}$cells during the first 7 months of life, particularly during the first month where proliferation was increased in the basis relative to tegmentum. The majority of proliferative cells in the postnatal pons expressed the transcription factor Olig2, suggesting an oligodendrocyte lineage. The proportion of proliferating cells that were Olig2 ${ }^{+}$was similar through the first 7 months of life and between basis and tegmentum. The number of $\mathrm{Ki} 67^{+}$cells declined dramatically from birth to 7 months and further decreased by 3 years, with a small number of $\mathrm{Ki} 7^{+}$cells observed throughout childhood. In addition, two populations of vimentin/nestin-expressing cells were identified: a dorsal group near the ventricular surface, which persists throughout childhood, and a parenchymal population that diminishes by 7 months and was not evident later in childhood. Together, our data reveal remarkable postnatal growth in the ventral pons, particularly during infancy when cells are most proliferative and myelination increases.

\section{Keywords}

brainstem; pediatric; development; basis; pontine glioma; nif-0000-00217; SciRes_000114; AB_304558; AB_2109815; AB_442102; AB_396287; AB_92396; AB_91107; AB_291466; AB_2336877; AB_2336878; AB_261856; AB_2304493

\section{INTRODUCTION}

The human pons, part of the brainstem, is an important relay for sensory and motor information from the forebrain to the cerebellum. In addition, the pons plays essential roles in respiration, sleep, swallowing, eye movement, hearing, facial movement/sensation, posture, and maintenance of consciousness (Saladin, 2012). Anatomically, the pons can be divided into three regions: tectum, tegmentum, and basis. The tectum is the most dorsal component and forms the roof of the $4^{\text {th }}$ ventricle. The tegmentum is also located dorsally within the pons and contains important autonomic structures, as well as nuclei of cranial nerves V-VIII, which control various facial movements and sensation. The ventral portion of the pons is occupied by the basis pontis. Pontine nuclei within the basis receive inputs from descending corticopontine fibers and project to the cerebellum via the middle cerebellar peduncle.

During embryogenesis, the pons and cerebellum are formed from the metencephalon, which is derived from the rostral hindbrain (rhombencephalon) (Barkovich et al., 2009). In humans, pontine nuclei are derived from a stream of cells migrating from the rhombic lip termed the corpus pontobulbare between 8 and 20 weeks gestation (Essick, 1912). While a number of studies describe the development of the fetal pons (Fischbein et al., 1996; Hatta et al., 2007; Nozaki et al., 1992), less is known about postnatal pontine growth in humans, particularly at the cellular level. An improved understanding of the dynamics of growth and development of the human pons, particularly postnatal stem/progenitor populations, may provide insight into the development of this critical brain region and into abnormalities of the pons such as developmental malformations and pediatric gliomas (Barkovich et al., 2009). In this study, we quantified spatial and temporal growth profiles of the human pons throughout childhood utilizing MRI-based morphometry. In addition, we examined cell 
proliferation and expression of progenitor markers as a function of age and location within the pons.

\section{MATERIALS AND METHODS}

\section{Brainstem morphometry}

All brain MRI studies were approved by the University of California, San Francisco Committee on Human Research. MRI scans obtained between 2005 and 2010 and for which there were no intracranial abnormalities (as noted by the official report of the neuroradiologist who interpreted the scan as part of routine clinical care) were included in the study ( $\mathrm{n}=123)$. For volumetric assessments (total pons, medulla, pontine tegmentum, basis pontis), T1-weighted sequences were evaluated. In addition, average T2 values for both basis and tegmentum were measured from mid-pons axial images, and the ratio of $\mathrm{T} 2$ intensities were used to estimate myelination in these two regions (modification of method described by Abe et al., 2004). For each MRI, consecutive axial images extending from rostral pons (at midbrain-pons junction, just caudal to cerebral peduncles) to distal medulla (cervicomedullary junction) were analyzed. The areas (in $\mathrm{mm}^{2}$ ) of regions of interest (pontine tegmentum, pontine basis, medulla) were manually traced for each axial image and the volume (in $\mathrm{mm}^{3}$ ) estimated using measurement tools from Philips iSite Enterprise (version 3.6) radiology software (Figure 1). Age groups evaluated were age 0 (within three days of birth, normal gestational age), $3 \mathrm{mo}, 6 \mathrm{mo}, 9 \mathrm{mo}, 1 \mathrm{yr}, 3 \mathrm{yr}, 5 \mathrm{yr}, 7 \mathrm{yr}, 9 \mathrm{yr}, 11 \mathrm{yr}, 13$ $\mathrm{yr}$, and $18 \mathrm{yr}(\mathrm{n}=123)$. Average volumetric growth rates for basis, tegmentum, and medulla $\left(\mathrm{mm}^{3} / \mathrm{mo}\right)$ were calculated between age groups $(0-3 \mathrm{mo}, 3-6 \mathrm{mo}, 6 \mathrm{mo}-1 \mathrm{yr}, 1-3 \mathrm{yr}, 3-5$ $\mathrm{yr}, 5-7 \mathrm{yr}, 7-18 \mathrm{yr}$ ) by calculating the difference in volumetric averages of the two age groups (in $\mathrm{mm}^{3}$ ) and dividing by the time between ages (in mo).

\section{Human brainstem specimens and tissue preparation}

Samples of postmortem human pons were collected from two sources $(\mathrm{n}=10$, Table 1). Specimens obtained at autopsy within the UCSF Department of Pathology as part of standard operating procedure were transferred to $4 \%$ paraformaldehyde within 72 hours of death. All tissues were collected in accordance with the University of California San Francisco Committee on Human Research. Additional specimens harvested <24 hours postmortem and stored in 10\% formalin fixative were obtained from the National Institute of Child Health and Human Development Brain and Tissue Bank for Developmental Disorders at the University of Maryland, Baltimore (contract HHSN275200900011C, ref. N01HD-9-0011, RRID: nif-0000-00217). Fixative storage intervals for specimens included in the analysis ranged from 0-3 yrs. For quality control purposes, autopsy specimens that were grossly damaged or did not stain for the nuclear marker DAPI were excluded. All samples included in the analysis were derived from patients with no evidence of intracranial abnormalities.

Axial blocks of approximately $5 \mathrm{~mm}$ thickness were cryoprotected in $30 \%$ sucrose solution, snap frozen in OCT compound (Tissue-Tek, Torrance, CA) using dry ice, and placed in a $-80^{\circ} \mathrm{C}$ freezer for equilibration. Axial $18-20 \mu \mathrm{m}$ thick sections were collected using a 
standard cryotome and mounted on glass slides (Superfrost Plus, Fischer Scientific, Waltham, MA).

\section{Immunohistochemistry}

After rinses in TNT wash buffer (1X Phosphate Buffered Saline, 0.05\% Triton X-100), microwave or water bath antigen retrieval was performed for all sections in $0.01 \mathrm{M}$ citrate buffer ( $\mathrm{pH} \mathrm{6.0)}$ at $95^{\circ} \mathrm{C}$ for 10 minutes, followed by a 20 min cooling period. After rinsing in TNT, slides were incubated with $1-2 \% \mathrm{H}_{2} \mathrm{O}_{2}$ for $30-60$ minutes at room temperature to block endogenous peroxidase activity. Slides were then incubated in TNB blocking solution (0.1QM Tris- $\mathrm{HCl}, \mathrm{pH} 7.5,0.15 \mathrm{QM} \mathrm{NaCl}, 0.5 \%$ blocking reagent from PerkinElmer, Waltham, MA) for 30 minutes at room temperature, followed by overnight incubation in primary antibodies (see Table 2 for details of primary antibodies used). Sections were then incubated for 90 minutes in biotinylated secondary antibodies (dilution 1:500; JacksonImmuno, West Grove, PA) for Ki67, nestin, mouse Olig2, and anti-myelin basic protein (MBP) primary antibodies and/or direct fluorophore-conjugated secondary antibodies (dilution 1:500; Life Technologies, Grand Island, NY) for vimentin, rabbit Olig2 antibodies, and GFAP primary antibodies. All secondary antibodies were diluted in TNB along with DAPI at 1:10000 dilution. Biotinylated sections were then incubated in streptavidin-horseradish peroxidase (PerkinElmer) for 30Qmin, followed by application of DAB Peroxidase Substrate Kit (MBP, Vector Labs, Burlingame, CA) for 7.5 minutes or TSA fluorescent amplification (nestin, Ki67, mouse vimentin) for 4-5 minutes, which utilizes fluorescent conversion of tyramide substrates (PerkinElmer). For double-labeling studies, a similar protocol was employed, with the exception of administering both a biotinylated and direct fluorophore-conjugated secondary antibody simultaneously in the secondary antibody incubation step.

\section{Antibody Characterization}

The details of the primary antibodies used in the study are included in Table 2. The chicken polyclonal antibody against GFAP was characterized by the manufacturer in a Western blot analysis of brain tissue lysate, yielding bands at $55 \mathrm{kDa}$ and $48 \mathrm{kDa}$, as well as by flow cytometry of human brain cells. The mouse monoclonal GFAP antibody was previously characterized by Western blot of human glioma cell lines, yielding a band at $51 \mathrm{kDa}$, while no band was detected in human RD cells that lack GFAP (Debus et al., 1983). The rabbit polyclonal Ki67 antibody was characterized by the manufacturer to localize to the nucleus of normal and neoplastic human tissue. The mouse monoclonal Ki67 antibody was tested in Western blot of proliferating cells by the manufacturer, yielding bands at 395 and $345 \mathrm{kDa}$, and immunohistochemical staining in human tonsil yielded similar results to MIB-1 antibody that also reacts with Ki67. For the rabbit polyclonal against human myelin basic protein, manufacturer data indicates Western blot detected bands in mouse brain lysate (14, 17,18 , and $21 \mathrm{kDa}$ ), and a recent study demonstrated co-localization of this antibody with other myelin components using human adult brain immunohistochemistry (Roig et al., 2010). Western blot analysis of the rabbit polyclonal anti-nestin antibody in two distinct human glioma cell line lysates revealed a single band between 220 and $240 \mathrm{kDa}$ (Messam et al., 2000). Likewise, manufacturer information for the mouse monoclonal anti-nestin antibody indicates human specificity with a 220-240 kDa band detected by Western blot. 
The rabbit anti-Olig2 antibody was characterized via Western blot of human normal human cortex and human glioma lysates (38 kDa band), as well as co-localization with PDGFRapositive cells in human fetal white matter using double-label immunohistochemistry (Ligon et al., 2004). Specificity of the mouse monoclonal anti-Olig2 antibody was demonstrated by a lack of staining in Olig2-null brain tissue immunohistochemistry (Ligon et al., 2006). The mouse IgM anti-vimentin antibody labeled the expected $60 \mathrm{kDa}$ band in Western blot of human sarcoma cells (Stathopoulos et al., 1989), and Western blot of human HeLa cell lysate using the mouse $\mathrm{IgG}$ anti-valentine antibody recognized a band at $50 \mathrm{kDa}$ (Bohn et al., 1992).

For all antibodies listed, the staining protocol was optimized in single-labeling studies after varying antigen retrieval ( \pm citrate antigen retrieval), primary antibody concentration (dilution series), and secondary antibody method (fluorophore-conjugated secondary antibody versus biotinylated with TSA amplification). Given the paucity of data in the human pons for expression of the antigens of interest (Ki67, Olig2, vimentin, nestin), two independent primary antibodies, typically different host species and clonality (see Table 2), were utilized for each antigen to ensure specificity/sensitivity of the antibodies. Only those antibodies which produced a spatial and temporal distribution that could be confirmed with at least one other antibody were used for the study. For myelin immunohistochemistry with anti-MBP, a similar spatial and temporal pattern of myelin staining was confirmed with Luxol Fast Blue. In addition, for both single- and double-label experiments, parallel sections incubated without primary antibodies were performed as negative controls. Using this method, the observed nestin and vimentin pattern lining the fourth ventricle within the dorsal pons was in agreement with a recent study on the human pons (Monje et al., 2011). While the lack of previous reports on Olig2 and Ki67 distribution in the developing human pons prevent direct comparison, a consistent spatial and temporal distribution for each antigen was confirmed with multiple antibodies. In addition, the Olig2 and Ki67 antibodies used in this study have been previously used to detect these antigens in human brain material (Ligon et al., 2004; Ligon et al., 2006; Quinones-Hinojosa et al., 2006).

\section{Assessment of cell proliferation}

For quantitation and mapping of cell proliferation, mid-pons axial hemisections immunostained for Ki67 were tiled at 10X magnification on an epifluorescence microscope using Stereo Investigator automated image capture system (MBF Bioscience, Williston, VT; RRID: SciRes_000114). Offline, all proliferating cells were marked for subsequent analysis by a blinded investigator. Criteria for inclusion as a positive Ki67 cell included clear nuclear staining of Ki67, co-localization with the nuclear marker DAPI, and lack of nonspecific staining in the same distribution. After defining tegmentum and basis contours for each hemisection, average cell density (\# Ki67 ${ }^{+}$cells $/ \mathrm{mm}^{2}$ ) for total pons, tegmentum, and basis was tabulated. Specimens were grouped into one of five age groups: I (1 day, $1 \mathrm{mo}$ ), II (2 mo, $7 \mathrm{mo}$ ), III (1.5 yr, $3 \mathrm{yr}$ ), IV (7 yr, 8yr), and V (13 yr, $13.5 \mathrm{yr}$ ). In addition, spatial distribution maps for tegmentum and basis as a function of postnatal age were plotted using StereoInvestigator software. 


\section{Olig2/Ki67 quantification}

Confocal images were captured on a Leica TCS SP5 AOBS microscope (Leica

Microsystems, Buffalo Grove, IL) using a 20X objective with 2.72X optical zoom to a resolution of $0.279 \mathrm{Vm}$ per pixel. Images were collected by automated acquisition of 0.08 $\mathrm{mm}^{2}$ fields containing only basis or only tegmentum. Between 30 and 200 fields were collected per region depending on the specimen size. Images were collected at four wavelengths corresponding to DAPI (405 nm laser), Olig2 (Alexa 488 / $488 \mathrm{~nm}$ laser), and Ki67 (Cy3/543nm laser). In addition, an unstained channel (633 laser) was collected to identify regions of nonspecific fluorescence. For each section, the number of $\mathrm{Ki}^{+} 7^{+}$and Ki $67^{+} /$Olig $2^{+}$cells were counted by a blinded observer, and the percentage of doublepositive cells $\left(\mathrm{Ki}_{6} 7^{+} \mathrm{Olig} 2^{+} / \mathrm{Ki} 67^{+}\right)$was calculated for tegmentum and basis at $0-1$ mo and 2-7 mo.

\section{Brightfield imaging of myelin stains}

Tissue sections were labeled with anti-MBP antibody and detected by DAB staining as described above, then counterstained with Gill's hematoxylin \#3 (Polysciences, Warrington, PA). Brightfield images were acquired on a DMI4000B microscope with DFC295 color camera (Leica), using LAS AF software to perform an automated tile scan of entire hemisections under a $5 \mathrm{x}$ objective, and to capture higher-resolution images of specific regions under a 20x objective.

\section{Analysis}

A one-way ANOVA was used to evaluate $\mathrm{T} 2$ ratio data and total proliferation levels as a function of time. For regional analysis of proliferation and percentage of proliferating cells that were Olig2 $2^{+}$, a two-way ANOVA was performed to evaluate the importance of age, location, and age-location interaction on the dependent variable. Tukey post-hoc comparisons were utilized to examine within and between group differences for each ANOVA. $\mathrm{p}<0.05$ was considered significant for all statistical tests.

\section{RESULTS}

\section{The human pons expands its volume 6-fold during postnatal child development}

We first compared the postnatal growth of the medulla and pons using MRI scans from children ranging in age from birth to 18 years of age ( $n=10-15 /$ time point). We subdivided the pons into dorsal (tegmentum) and ventral (basis) regions. Figure 1 illustrates the areas studied in the sagittal and axial planes. Volumetric analysis of the postnatal human pons revealed a dramatic growth over the first several years of life, with a tripling of the total pons volume in the first 6 months (average growth rate of $532.9 \mathrm{~mm} / \mathrm{mo}$ ), and an additional doubling between the ages of $6 \mathrm{mo}$ and $5 \mathrm{yr}\left(\mathrm{rate}=106.1 \mathrm{~mm}^{3} / \mathrm{mo}\right.$ ) (Figure 2A). Between 5 and 18 years there was continued growth of the pons, though at a more modest rate (13.7 $\mathrm{mm}^{3} / \mathrm{mo}$ ). In contrast to the pons, the volume of the medulla showed less expansion over the same time periods, with growth rates of $118.7,19.6$, and $-0.2 \mathrm{~mm}^{3} / \mathrm{mo}$ over the $0-6 \mathrm{mo}, 6$ mo $-5 \mathrm{yr}$, and 5-18 yr time periods, respectively. 
Regional analysis showed that the growth of the pons was primarily due to a dramatic increase in the volume of the basis as compared to the tegmentum (Figure 2B). Consistent with this preferential growth of the basis, the ratio of basis to tegmentum volume increased from 1.5 at birth to 2.0 at 3-6 months and stabilized at 2.3-2.7 for the remainder of childhood (Figure 2C). The average volumetric growth rates of the pontine basis as a function of postnatal age (Figure 2D) revealed three phases of growth. In the first three months of life, the basis dramatically expanded in volume, with a growth rate of approximately $500 \mathrm{~mm}^{3} / \mathrm{mo}$. Between 3 months and 1 year, the expansion rate decreased to $225 \mathrm{~mm}^{3} / \mathrm{mo}$ and remained constant over this interval. After 1 year, the growth rate gradually declined to near zero from 7 years onward. In contrast, medulla and tegmentum growth rates had dramatically declined by 3-6 mo and 6 mo-1 year, respectively.

We next compared the T2 intensity signal in our MRI section analysis. T2 is a reflection of water content in the tissue and is inversely related to the amount of myelination (Abe et al., 2004). The ratio of $\mathrm{T} 2$ intensity between basis and tegmentum (Figure $3 \mathrm{~A}$ ) decreased significantly throughout childhood (1-way ANOVA; $\mathrm{F}_{10,90}=26.273$, $\mathrm{p}<0.001$ ), ranging from 1.14 at birth to 0.85 at age 18 . Tukey post-hoc analysis revealed that the T2 ratio at birth was significantly higher than all other time points $(\mathrm{p}<0.001)$ and the ratio at 3 mo was significantly higher than $6 \mathrm{mo}, 9 \mathrm{mo}$, and $1 \mathrm{yr}(\mathrm{p}<0.01)$. T2 ratio was not statistically different between any other timepoints between $6 \mathrm{mo}$ and $18 \mathrm{yr}$. These observations suggest that the dramatic growth of the basis during the first phase may be due in part to increased myelination. Because our T2 MRI data suggested a relative increase in myelination of the basis during the first 6 months, we performed DAB-based immunostaining of myelin basic protein in pons sections (Figure 3B-J). We observed an increase in the extent of myelination from 1 day to 7 months, clearly visible as a progressive thickening of myelinated tracts in the basis, including the longitudinal fibers of the corticospinal tract (CST) and the horizontally oriented fibers within the pontine nuclei (PN). Myelination increased further from 7 months to 3 years of age. Myelin distribution at ages older than 3 years was similar to 3-year samples, and similar results were obtained by labeling myelin with Luxol Fast Blue dye (data not shown).

\section{Spatial and temporal profile of proliferation in the postnatal human pons}

The dramatic growth of the pons during postnatal life, and in particular of the basis, could be due to the addition of new cells, growth and addition of cellular processes, or both. The T2 MRI analysis and MBP immunohistochemistry suggested that increased myelination may partially account for this growth, particularly during the first 6 months of life. In order to determine the contribution of cell proliferation to pontine growth, we used 12 post-mortem fixed human brainstem samples ranging from birth to 15 years of age (Table 1). The density of proliferating cells in the entire pons, defined as the number of Ki67 ${ }^{+}$cells per $\mathrm{mm}^{2}$, was determined in $20 \mathrm{Vm}$ transverse sections (Figure 4A). The proliferating cell density decreased significantly with increasing age (one-way ANOVA; $\mathrm{F}_{4,5}=49.77, \mathrm{p}<0.001$ ), and a significantly higher density of Ki67 ${ }^{+}$cells was observed in the $0-1$ mo group (I, 28.1 cells $/ \mathrm{mm}^{2}$ ) compared to all other groups (Tukey post-hoc comparison; $\mathrm{p}<0.001$ ). In the $2-7$ month group (II), the density of Ki67 ${ }^{+}$was reduced approximately 10 -fold $\left(2.6 \mathrm{cells} / \mathrm{mm}^{2}\right.$ ) 
compared to the $0-1$ month group. From $2-13$ years of age (Groups III-V), very low levels of proliferation were observed $\left(0.09-0.17\right.$ cells $\left./ \mathrm{mm}^{2}\right)$ (Figure 4B-C).

A similar analysis of proliferation was performed separately for the tegmentum and basis (Figure 4D-E). A two-way ANOVA revealed that proliferation density was a function of time $\left(\mathrm{F}_{4,10}=49.01, \mathrm{p}<0.001\right)$ and location $\left(\mathrm{F}_{1,10}=7.52, \mathrm{p}<0.05\right)$, and there was a significant interaction between time and location $\left(\mathrm{F}_{4,10}=8.32, \mathrm{p}<0.003\right)$. Tukey post-hoc analysis indicated that proliferation was higher at $0-1$ mo (Group I) compared to all other timepoints for both tegmentum $(\mathrm{p}<0.02)$ and basis $(\mathrm{p}<0.001)$. In addition, at $0-1$ mo, proliferation was higher $(\mathrm{p}<0.001)$ in the basis $\left(36.1\right.$ cells $\left./ \mathrm{mm}^{2}\right)$ compared to tegmentum $\left(15.5 \mathrm{cells} / \mathrm{mm}^{2}\right)$. At the later 4 time points examined in the subregion analysis (Groups II-V), proliferating cell density within and between the two pons regions was not statistically different.

In order to detect possible foci of proliferation that may be overlooked by counting Ki67+ cells throughout the pons, we constructed spatial maps to assess the distribution of proliferation within the pons as a function of postnatal age (Figure 5). In samples from 1-day brains, a higher density of proliferating cells was seen throughout the pons as compared to later time points. In addition, there was an increased density of Ki67 $7^{+}$cells within the basis compared to the tegmentum, particularly in the ventral and lateral basis. Interestingly, at this very early postnatal age, $\mathrm{Ki} 67^{+}$cells were observed in clusters within white matter tracts (cerebellar peduncle, corticospinal tracts, and transverse pontine fibers). Higher levels of proliferation were also noted throughout the pons at 1 month, with corresponding increased Ki $67^{+}$cell density within the basis relative to tegmentum. However, the proliferating cells were distributed in a more homogeneous manner. At 7 months, the number of Ki67 $7^{+}$cells was markedly lower, and the relative density of proliferating cells was similar in the basis and tegmentum. In all brainstem samples analyzed from ages $1.5-13 \mathrm{yr}, \mathrm{Ki}^{+} 7^{+}$cells were rare and distributed throughout the basis and the tegmentum. The above results suggest abundant cell proliferation during the first 7 months after birth, with particularly high numbers during the first month. In order to address the possibility that the observed proliferative cells might be reactive astrocytes, we performed co-immunofluorescence for Ki67 and the astrocyte marker GFAP (Figure 6F). Confocal microscopy demonstrated that $\mathrm{GFAP}^{+}$processes did not surround $\mathrm{Ki} 7^{+}$nuclei. In fact, we observed no reactive astrocytes in our autopsy samples, but rather a network of normal, thin $\mathrm{GFAP}^{+}$astrocyte processes throughout the tissue.

\section{Majority of postnatal proliferating cells are Olig2+}

The MRI-based morphometric data showed robust growth and increased myelination in the early postnatal pons. The histological analysis of pontine postmortem tissue also showed cellular proliferation in the white matter regions. These observations led us to analyze the proportion of proliferating cells expressing Olig2, a progenitor marker that is frequently associated with the generation of oligodendrocytes. Human pons sections ranging from 1 day to 7 mo were double-labeled for Ki67 and Olig2, and the tegmentum and basis were analyzed (Figure 6 ). In the $0-1$ mo group, double-labeled Olig $2^{+} / \mathrm{Ki} 67^{+}$cells were seen in both the basis and the tegmentum. Increased density of both single-labeled $\left(\mathrm{Ki}^{+} \mathrm{7}^{+}\right)$and double-labeled $\left(\mathrm{Olig} 2^{+} / \mathrm{Ki} 67^{+}\right)$cells were observed in the basis relative to tegmentum. The 
majority of Ki67+ cells in the basis were Olig2 $2^{+}(57.0 \pm 3.5 \%)$, but single- labeled cells for either marker were also observed (Figure 6). By 2-7 months of age, the number of Ki67 ${ }^{+}$ and $\mathrm{Ki} 67^{+} / \mathrm{Olig} 2^{+}$cells declined in both pons locations relative to the $0-1$ month group, consistent with the proliferation analysis described earlier. However, despite the smaller number of proliferating cells in the 2-7 mo age group, the proportion of proliferating cells that were Olig2 ${ }^{+}$remained stable $(61.8 \pm 2.57 \%)$ and was not statistically different between pons subregions or when compared to $0-1$ mo data (Figure 6E).

\section{Nestin and vimentin expression in the postnatal human pons}

The above results indicate that more than half of the proliferating cells express Olig2. However, there was a significant fraction of $\mathrm{Ki} 67^{+}$cells that were Olig2- ${ }^{-}$. A recent study describing nestin- and vimentin-positive cell populations in the pons throughout childhood (Monje et al., 2011) suggested that some such cells may correspond to neural stem cells. We therefore examined the spatial and temporal profile of nestin- and vimentin-expressing cells in the pons ventricular zone, tegmentum, and basis. At postnatal day 1, a dense population of nestin $^{+}$, vimentin $^{+}$, and nestin ${ }^{+} /$vimentin $^{+}$cells was seen lining the ventricle (Figure 7). Interestingly, the majority of these cells had radial processes into the tegmentum, suggesting the postnatal persistence of a population of radial glia. At this early time point, we also observed nestin ${ }^{+} /$vimentin $^{+}$processes in both the tegmentum and basis. Interestingly, in the basis these double-labeled processes were oriented parallel to white matter tracts. A similar pattern of vimentin and nestin expression was observed at 1 and 2 months of age, although the total number of positive cells decreased. By 7 months, dorsal vimentin ${ }^{+} /$nestin $^{+}$cells remained present in the ventricular region, but only very rare single- or double-labeled cells were observed in the parenchyma of the tegmentum or basis. From 7 mo through the later childhood years, this spatial restriction of nestin and vimentin expression to the ventricular lining was maintained, although the number of vimentin ${ }^{+}$radial fibers, and to a greater degree the nestin ${ }^{+}$processes, decreased over time. No specific labeling of nestin ${ }^{+}$or vimentin $^{+}$processes was seen in the basis or tegmentum at any ages over 7 mo.

\section{DISCUSSION}

The present morphometric analysis of the human postnatal pons demonstrates substantial growth of the pons throughout childhood, particularly in the basis pontis. The MRI and histological studies suggest that this expansion of the ventral pons is at least in part due to addition of oligodendrocytes and increased myelination. This finding is consistent with previous immunohistochemical and radiographic data showing that while myelination of the tegmentum is largely complete by birth, an increase in myelination of the basis pontis is observed in the first 3-4 months of life (Brody et al., 1987; Kinney et al., 1988; Nozaki et al., 1992). At the cellular level, the wave of Olig2 ${ }^{+}$cell proliferation observed not only in the basis, but also to a lesser degree in the tegmentum, appears to peak early in postnatal life $(0-1$ month). Yet the pons continues to grow at high rates up to 1 year and at slower rates up to 5 years of age. This suggests that only some of the observed growth can be attributed to cell addition, and that the slow, steady growth observed from 1 to 5 years is likely due to increase in the neuropil, including expansion of the corticospinal tract. Consistent with this finding, a previous study demonstrated a decrease in neuronal number and volume in the 
pontine nuclei of the basis between birth and 2 months (Nozaki et al., 1992). Our data suggest that most of the growth after 1 year is related to increase in cellular processes and cellular size rather than cell number.

The tremendous growth of the human pons during infancy and childhood raises fundamental questions, not only of the basic cellular mechanisms that explain this expansion, but also about its functional correlates. Pontine growth is likely associated with consolidation of neural circuits for motor coordination and learned behaviors during this critical stage of human development, consistent with experimental data showing robust synaptogenesis and consolidation of cortico-pontine tracts in the early postnatal time period (Adams et al., 1980; Mihailoff et al., 1984). The ventral pool of proliferating Olig2 ${ }^{+}$cells within the basis pontis may be critical for the robust expansion of white matter tracts in this region during early postnatal life. While the source of this postnatal proliferative population in the pons is unclear, it raises the possibility that persistent primary progenitors in germinal niches of the postnatal brainstem, analogous to the rhombic lip present during fetal development, may continue to be a source of Olig2 ${ }^{+}$precursors. Alternatively, these precursors may be produced before birth, and migrate widely to proliferate and differentiate locally.

The present results are also relevant to better understand the origins of one of the most lethal types of pediatric brain tumors. Diffuse Intrinsic Pontine Glioma (DIPG) remains an important clinical problem, comprising 10-15\% of childhood brain tumors (Fangusaro, 2009). Patients typically present at 5-9 years of age and have a dismal prognosis, with a median survival of less than 1 year (Wagner et al., 2006). Genomic studies have identified several mutations found in DIPG, including H3F3A/ HIST1H3B (Wu et al., 2012), PDGFRA (Paugh et al., 2011; Puget et al., 2012; Zarghooni et al., 2010), TP53 (Grill et al., 2012) and ADAM3A (Barrow et al., 2011). Recent work suggests that progenitor cells give rise to other pediatric brain tumors, such as cerebellar granule cell precursor-derived medulloblastomas (Schuller et al., 2008), precerebellar neuronal precursor-derived medulloblastomas (Gibson et al., 2010), and radial glia-derived ependymomas (Taylor et al., 2005). Given the predominant ventral growth of DIPG (Fischbein et al., 1996) and a recent report of expression of progenitor markers in the postnatal human pons (Monje et al., 2011), it has been suggested that the ventral pons may contain the cell of origin for DIPG. In addition, a recent report demonstrated that $>90 \%$ of DIPGs express Olig2 (Ballester et al., 2013). These data, in combination with the findings in the present study, suggest some interesting hypotheses. First, the presence of a dorsal vimentin ${ }^{+} /$nestin $^{+}$cell population in the human pons throughout childhood suggests that this cell population may be a potential cell of origin for focal human brainstem tumors, which tend to occur dorsally in the region of the aqueduct of Sylvius/4th ventricle in the midbrain, pons, and medulla (Fischbein et al., 1996). Second, the scarcity of proliferative progenitors past early postnatal stages suggests that if DIPG originates from a proliferating cell in the ventral pons, oncogenic events would likely occur early in childhood, and it may take years for these tumors to become fully malignant. By contrast, if DIPG originates shortly before diagnosis (ages 5-9), a time period where we observed that pons growth is rapidly decelerating, then DIPG may derive from transformation of a nonproliferative cell, for example a Olig2 ${ }^{+} / \mathrm{Ki}^{-} 7^{-}$cell. We observed very low numbers of $\mathrm{Ki} 67^{+}$cells in the pons during the period when DIPG is most 
frequently diagnosed, although we cannot exclude that those rare dividing cells could be the origin of these tumors.

In summary, the present study provides a quantitative description of the extraordinary growth of the human pons during infancy and childhood. Our data indicate that both the tegmentum and the basis grow significantly during this period, but the basis pontis expands at rates higher than the tegmentum or the medulla. This preferential growth of the basis is at least in part mediated by increased myelination, consistent with the presence of large number of proliferating Olig2 ${ }^{+}$cells during early postnatal ages. These data, in conjunction with previous studies of brainstem development, suggest distinct cell populations as potential cells of origin for different brainstem tumors. Future studies evaluating the origin and fate of postnatal progenitor populations in model systems may give insight into the mechanisms of the postnatal growth of the pons and a possible cell of origin of pediatric pontine gliomas.

\section{Acknowledgments}

Grant Sponsors: National Institutes of Health (NS28478) and John G. Bowes Research Fund (AA-B), NRSA 1F32NS067889-01A1 (MT), Pediatric Brain Tumor Foundation (AAB, DHR), University of California MRPI \#142675 (EJH). DHR is a HHMI Investigator.

This work was supported by grants from the NIH (NS28478 to AA-B and 1F32NS067889-01A1 to MT), Pediatric Brain Tumor Foundation (to AA-B and DHR), University of California MRPI \#142675 (EJH), and a generous gift from the JG Bowes Foundation (AAB). Dr. Alvarez-Buylla is the Heather and Melanie Muss Endowed Chair. MT was supported by the UCSF Neurological Surgery Residency Program. RL is supported by the UCSF Medical Scientist Training Program, Neuroscience Graduate Program, and Discovery Fellows Program. DHR is a HHMI Investigator. AA-B is the Heather and Melanie Muss Endowed Chair and Professor of Neurological Surgery. The authors also wish to thank Jeanelle Ariza of the Pediatric Neuropathology Research Laboratory (UCSF, HHMI) for assistance with myelin staining and the laboratories of Drs. Arnold Kriegstein and Patrick McQuillen for assistance with automated microscopy techniques.

\section{LITERATURE CITED}

Abe S, Takagi K, Yamamoto T, Okuhata Y, Kato T. Semiquantitative assessment of myelination using magnetic resonance imaging in normal fetal brains. Prenat Diagn. 2004; 24(5):352-357. [PubMed: 15164408]

Adams CE, Parnavelas JG, Mihailoff GA, Woodward DJ. The neurons and their postnatal development in the basilar pontine nuclei of the rat. Brain Res Bull. 1980; 5(3):277-283. [PubMed: 7397572]

Ballester LY, Wang Z, Shandilya S, Miettinen M, Burger PC, Eberhart CG, Rodriguez FJ, Raabe E, Nazarian J, Warren K, Quezado MM. Morphologic characteristics and immunohistochemical profile of diffuse intrinsic pontine gliomas. Am J Surg Pathol. 2013; 37(9):1357-1364. [PubMed: 24076776]

Barkovich AJ, Millen KJ, Dobyns WB. A developmental and genetic classification for midbrainhindbrain malformations. Brain. 2009; 132(Pt 12):3199-3230. [PubMed: 19933510]

Barrow J, Adamowicz-Brice M, Cartmill M, MacArthur D, Lowe J, Robson K, Brundler MA, Walker DA, Coyle B, Grundy R. Homozygous loss of ADAM3A revealed by genome-wide analysis of pediatric high-grade glioma and diffuse intrinsic pontine gliomas. Neuro Oncol. 2011; 13(2):212222. [PubMed: 21138945]

Bohn W, Wiegers W, Beuttenmuller M, Traub P. Species-specific recognition patterns of monoclonal antibodies directed against vimentin. Experimental cell research. 1992; 201(1):1-7. [PubMed: 1612114] 
Brody BA, Kinney HC, Kloman AS, Gilles FH. Sequence of central nervous system myelination in human infancy. I. An autopsy study of myelination. Journal of neuropathology and experimental neurology. 1987; 46(3):283-301. [PubMed: 3559630]

Debus E, Weber K, Osborn M. Monoclonal antibodies specific for glial fibrillary acidic (GFA) protein and for each of the neurofilament triplet polypeptides. Differentiation; research in biological diversity. 1983; 25(2):193-203.

Essick CR. The development of the nuclei pontis and the nucleus arcuatus in man. Am J Anatomy. 1912; 13:25-54.

Fangusaro J. Pediatric high-grade gliomas and diffuse intrinsic pontine gliomas. J Child Neurol. 2009; 24(11):1409-1417. [PubMed: 19638636]

Fischbein NJ, Prados MD, Wara W, Russo C, Edwards MS, Barkovich AJ. Radiologic classification of brain stem tumors: correlation of magnetic resonance imaging appearance with clinical outcome. Pediatr Neurosurg. 1996; 24(1):9-23. [PubMed: 8817611]

Gibson P, Tong Y, Robinson G, Thompson MC, Currle DS, Eden C, Kranenburg TA, Hogg T, Poppleton H, Martin J, Finkelstein D, Pounds S, Weiss A, Patay Z, Scoggins M, Ogg R, Pei Y, Yang ZJ, Brun S, Lee Y, Zindy F, Lindsey JC, Taketo MM, Boop FA, Sanford RA, Gajjar A, Clifford SC, Roussel MF, McKinnon PJ, Gutmann DH, Ellison DW, Wechsler-Reya R, Gilbertson RJ. Subtypes of medulloblastoma have distinct developmental origins. Nature. 2010; 468(7327): 1095-1099. [PubMed: 21150899]

Grill J, Puget S, Andreiuolo F, Philippe C, MacConaill L, Kieran MW. Critical oncogenic mutations in newly diagnosed pediatric diffuse intrinsic pontine glioma. Pediatr Blood Cancer. 2012; 58(4): 489-491. [PubMed: 22190243]

Hatta T, Satow F, Hatta J, Hashimoto R, Udagawa J, Matsumoto A, Otani H. Development of the pons in human fetuses. Congenit Anom (Kyoto). 2007; 47(2):63-67. [PubMed: 17504389]

Kinney HC, Brody BA, Kloman AS, Gilles FH. Sequence of central nervous system myelination in human infancy. II. Patterns of myelination in autopsied infants. Journal of neuropathology and experimental neurology. 1988; 47(3):217-234. [PubMed: 3367155]

Ligon KL, Alberta JA, Kho AT, Weiss J, Kwaan MR, Nutt CL, Louis DN, Stiles CD, Rowitch DH. The oligodendroglial lineage marker OLIG2 is universally expressed in diffuse gliomas. Journal of neuropathology and experimental neurology. 2004; 63(5):499-509. [PubMed: 15198128]

Ligon KL, Kesari S, Kitada M, Sun T, Arnett HA, Alberta JA, Anderson DJ, Stiles CD, Rowitch DH. Development of NG2 neural progenitor cells requires Olig gene function. Proceedings of the National Academy of Sciences of the United States of America. 2006; 103(20):7853-7858. [PubMed: 16682644]

Messam CA, Hou J, Major EO. Coexpression of nestin in neural and glial cells in the developing human CNS defined by a human-specific anti-nestin antibody. Experimental neurology. 2000; 161(2):585-596. [PubMed: 10686078]

Mihailoff GA, Adams CE, Woodward DJ. An autoradiographic study of the postnatal development of sensorimotor and visual components of the corticopontine system. J Comp Neurol. 1984; 222(1): 116-127. [PubMed: 6321562]

Monje M, Mitra SS, Freret ME, Raveh TB, Kim J, Masek M, Attema JL, Li G, Haddix T, Edwards MS, Fisher PG, Weissman IL, Rowitch DH, Vogel H, Wong AJ, Beachy PA. Hedgehogresponsive candidate cell of origin for diffuse intrinsic pontine glioma. Proceedings of the National Academy of Sciences of the United States of America. 2011; 108(11):4453-4458. [PubMed: 21368213]

Nozaki H, Goto N, Nara T. Development of the human pontine nuclei: a morphometric study. Brain Res Dev Brain Res. 1992; 65(1):13-20.

Paugh BS, Broniscer A, Qu C, Miller CP, Zhang J, Tatevossian RG, Olson JM, Geyer JR, Chi SN, da Silva NS, Onar-Thomas A, Baker JN, Gajjar A, Ellison DW, Baker SJ. Genome-wide analyses identify recurrent amplifications of receptor tyrosine kinases and cell-cycle regulatory genes in diffuse intrinsic pontine glioma. J Clin Oncol. 2011; 29(30):3999-4006. [PubMed: 21931021]

Puget S, Philippe C, Bax DA, Job B, Varlet P, Junier MP, Andreiuolo F, Carvalho D, Reis R, GuerriniRousseau L, Roujeau T, Dessen P, Richon C, Lazar V, Le Teuff G, Sainte-Rose C, Geoerger B, Vassal G, Jones C, Grill J. Mesenchymal transition and PDGFRA amplification/mutation are key 
distinct oncogenic events in pediatric diffuse intrinsic pontine gliomas. PLoS One. 2012;

7(2):e30313. [PubMed: 22389665]

Quinones-Hinojosa A, Sanai N, Soriano-Navarro M, Gonzalez-Perez O, Mirzadeh Z, Gil-Perotin S, Romero-Rodriguez R, Berger MS, Garcia-Verdugo JM, Alvarez-Buylla A. Cellular composition and cytoarchitecture of the adult human subventricular zone: a niche of neural stem cells. J Comp Neurol. 2006; 494(3):415-434. [PubMed: 16320258]

Roig B, Franco-Pons N, Martorell L, Tomas J, Vogel WF, Vilella E. Expression of the tyrosine kinase discoidin domain receptor 1 (DDR1) in human central nervous system myelin. Brain research. 2010; 1336:22-29. [PubMed: 20380825]

Saladin, KS. Anatomy \& physiology: the unity of form and function. New York, NY: McGraw-Hill; 2012. p. xxvip. 1136-1186.

Schuller U, Heine VM, Mao J, Kho AT, Dillon AK, Han YG, Huillard E, Sun T, Ligon AH, Qian Y, Ma Q, Alvarez-Buylla A, McMahon AP, Rowitch DH, Ligon KL. Acquisition of granule neuron precursor identity is a critical determinant of progenitor cell competence to form Shh-induced medulloblastoma. Cancer Cell. 2008; 14(2):123-134. [PubMed: 18691547]

Stathopoulos E, Naeve GS, Taylor CR, Epstein AL. LN-6: a monoclonal antibody to vimentin expressed in non-hematopoietic mesenchymal cells and derived tumors and reactive in B5-fixed, paraffin-embedded tissues. The journal of histochemistry and cytochemistry: official journal of the Histochemistry Society. 1989; 37(9):1363-1370. [PubMed: 2671152]

Taylor MD, Poppleton H, Fuller C, Su X, Liu Y, Jensen P, Magdaleno S, Dalton J, Calabrese C, Board J, Macdonald T, Rutka J, Guha A, Gajjar A, Curran T, Gilbertson RJ. Radial glia cells are candidate stem cells of ependymoma. Cancer Cell. 2005; 8(4):323-335. [PubMed: 16226707]

Wagner S, Warmuth-Metz M, Emser A, Gnekow AK, Strater R, Rutkowski S, Jorch N, Schmid HJ, Berthold F, Graf N, Kortmann RD, Pietsch T, Sorensen N, Peters O, Wolff JE. Treatment options in childhood pontine gliomas. J Neurooncol. 2006; 79(3):281-287. [PubMed: 16598416]

Wu G, Broniscer A, McEachron TA, Lu C, Paugh BS, Becksfort J, Qu C, Ding L, Huether R, Parker M, Zhang J, Gajjar A, Dyer MA, Mullighan CG, Gilbertson RJ, Mardis ER, Wilson RK, Downing JR, Ellison DW, Baker SJ. Somatic histone H3 alterations in pediatric diffuse intrinsic pontine gliomas and non-brainstem glioblastomas. Nat Genet. 2012; 44(3):251-253. [PubMed: 22286216]

Zarghooni M, Bartels U, Lee E, Buczkowicz P, Morrison A, Huang A, Bouffet E, Hawkins C. Wholegenome profiling of pediatric diffuse intrinsic pontine gliomas highlights platelet-derived growth factor receptor alpha and poly (ADP-ribose) polymerase as potential therapeutic targets. J Clin Oncol. 2010; 28(8):1337-1344. [PubMed: 20142589] 

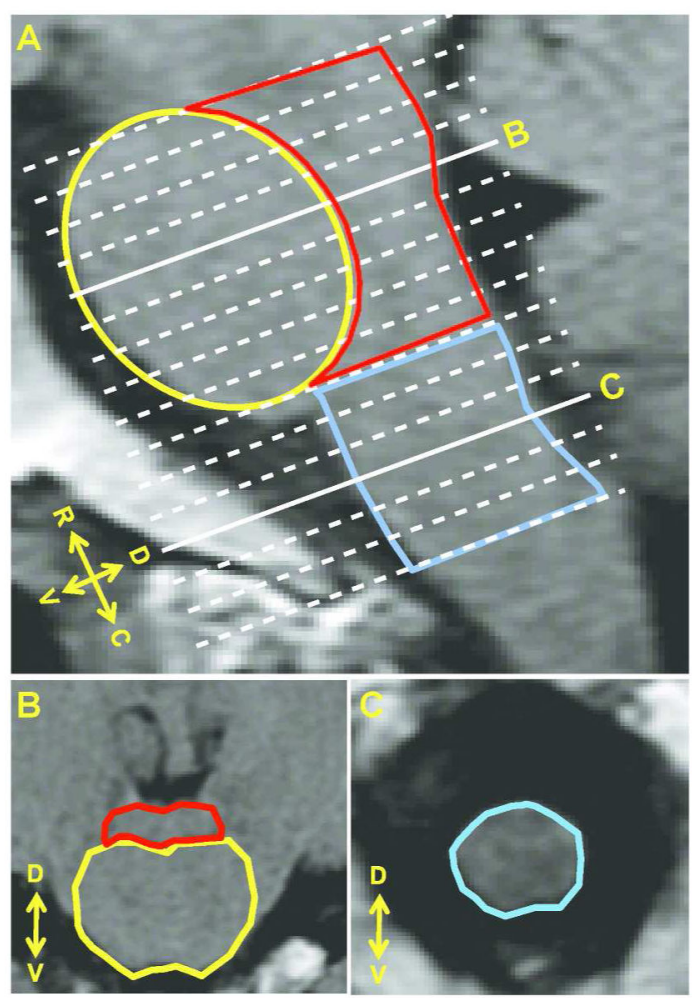

Figure 1. Brainstem morphometric measurements

The upper panel is an example mid-sagittal T1-weighted MRI showing the basis pontis (yellow), pontine tegmentum (red), and medulla (blue). Dashed lines illustrate the axial sections extending from proximal pons to distal medulla that were used to estimate volumes. For each cross section, the relevant brainstem subregions (tegmentum, basis, and medulla) were traced to determine the volume. The lower panels illustrate the tracing of axial images through mid-pons $(\mathrm{B}$, left) and mid-medulla $(\mathrm{C}$, right) levels. $\mathrm{D}=$ dorsal, $\mathrm{V}=$ ventral, $\mathrm{R}=$ rostral, $\mathrm{C}=$ caudal, $\mathrm{Rt}=$ right, $\mathrm{L}=$ left. 
A

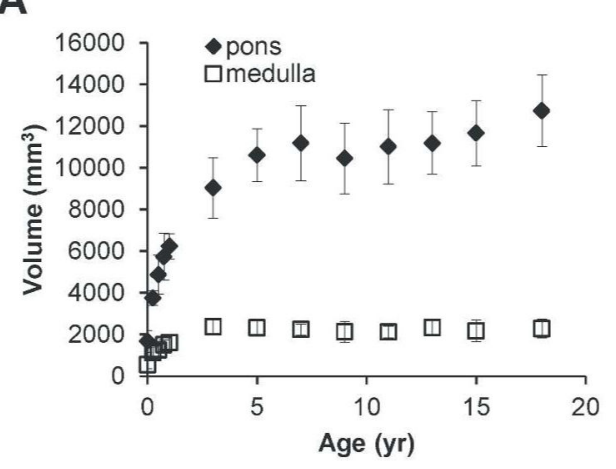

C

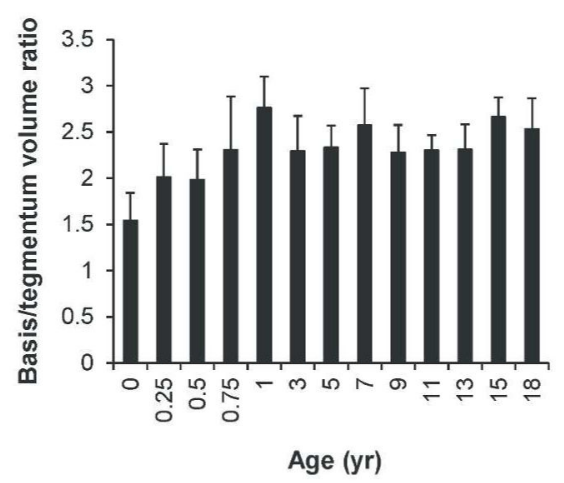

B

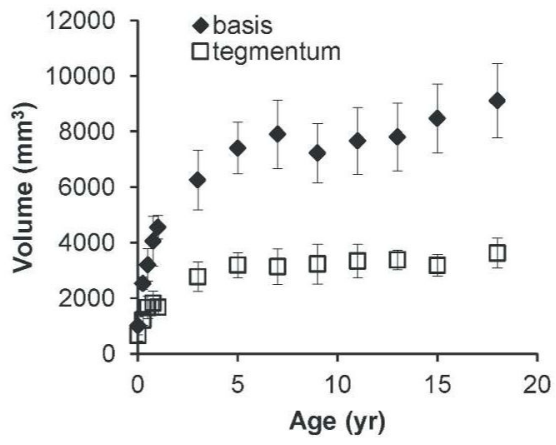

D

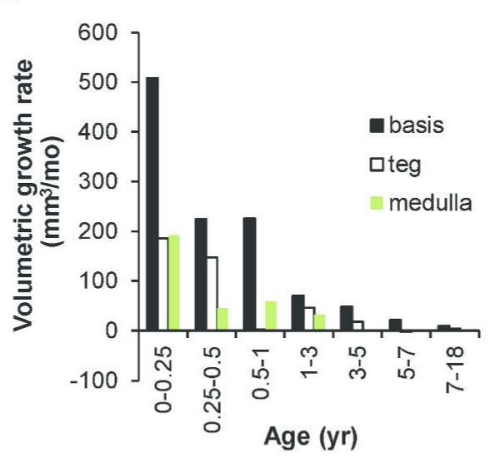

Figure 2. Brainstem volume measurements

A: Volume of pons and medulla $\left(\mathrm{mm}^{3}\right)$ as a function of postnatal age demonstrates robust and sustained growth in the pons compared to the medulla. B: Comparison of basis versus tegmentum volumes over time demonstrates that the majority of growth observed in the pons occurs in the basis. C: Analysis of the ratio of pons basis to tegmentum volume, illustrating increasing ratio over the first 6 months followed by stabilization for the remainder of childhood. D: In the basis pontis, volumetric growth rates are highest in the first 3 months, followed by decreased but steady growth up to 1 year that subsequently declines to near zero growth by 18 years. In contrast, the medulla and tegmentum growth rates rapidly declined by 3-6 mo and 6 mo -1 year, respectively. 

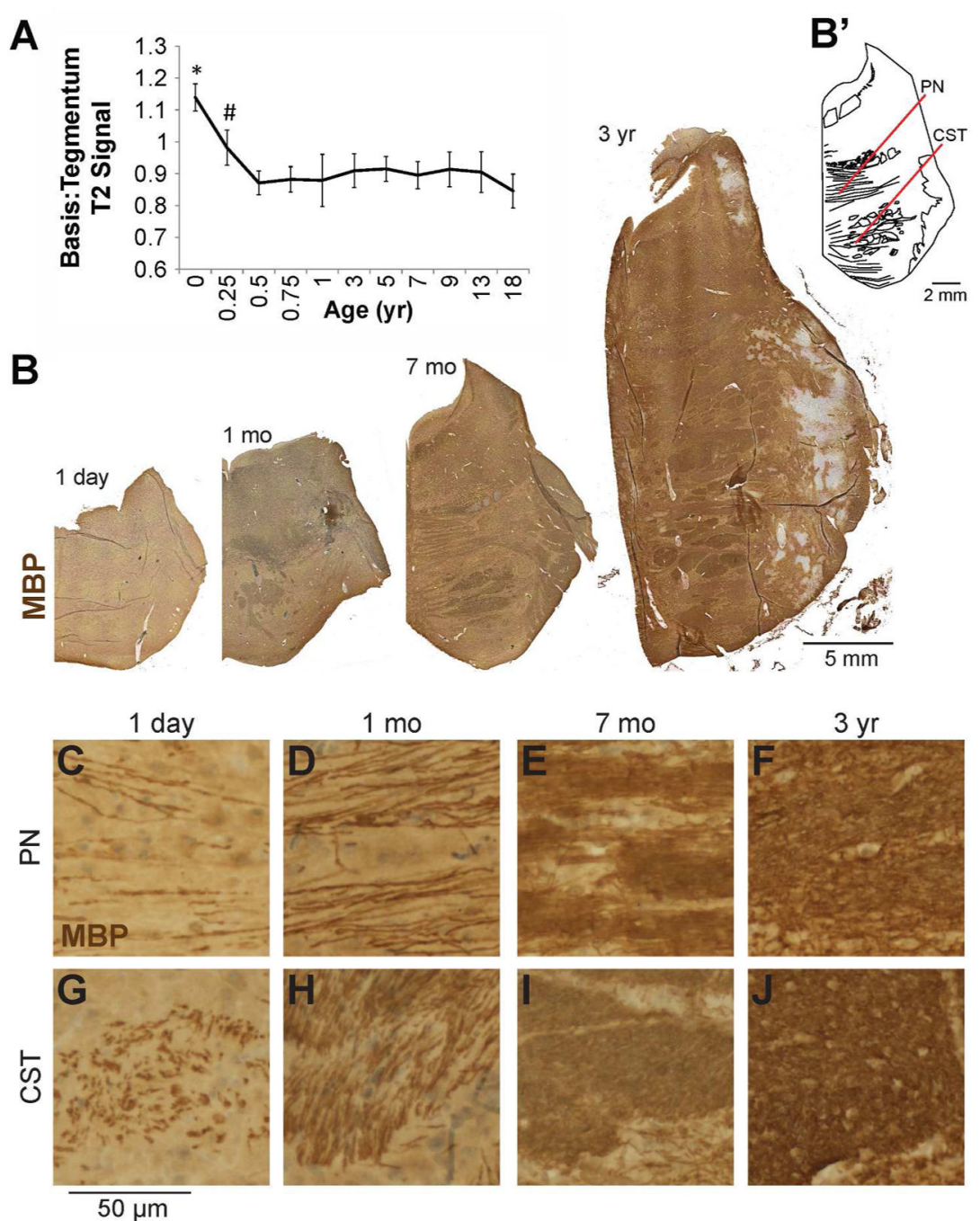

Figure 3. Myelination in the postnatal basis pontis

A: Quantification of the ratio of T2 signal in the basis relative to tegmentum, which is inversely correlated with the degree of myelination in the basis, indicating that myelination coincides with the observed early postnatal volumetric growth of the basis (Figure 2). Oneway ANOVA demonstrated a significant effect of age on $\mathrm{T} 2$ ratio $(\mathrm{F} 10,90=\mathrm{p}<0.001)$ and post-hoc Tukey comparison revealed a significant difference between age 0 and all other ages $(* \mathrm{p}<0.05)$ and between 3 months and 6 mo, 9 mo, and $1 \mathrm{yr}(\# \mathrm{p}<0.05) . \mathbf{B}$ :

Immunolabeling of myelin basic protein in pons hemisections (counterstained with hematoxylin) reveals progress of myelination during early childhood ( 1 day -3 yrs).

Samples aged older than 3 years were similar to 3-year samples (data not shown). $\mathbf{B}^{\prime}$ :

Schematic shows location of white matter tracts running through pontine nuclei (PN) and corticospinal tract (CST), shown at higher magnification in C-J. C-J: Fibers in both regions undergo significant increase of myelination from birth to 7 months and more modest increase from 7 months to 3 years. 
A

\begin{tabular}{|c|c|c|c|c|}
\cline { 2 - 5 } \multicolumn{1}{c|}{} & age & $\begin{array}{c}\text { basis } \\
\text { cells } / \mathrm{mm}^{2}\end{array}$ & $\begin{array}{c}\text { teg } \\
\text { cells } / \mathrm{mm}^{2}\end{array}$ & $\begin{array}{c}\text { total } \\
\text { cells } / \mathrm{mm}^{2}\end{array}$ \\
\hline \multirow{2}{*}{$\mathrm{I}$} & 1 day & 43.22 & 15.51 & 32.04 \\
& $1 \mathrm{mo}$ & 28.88 & 15.58 & 24.26 \\
\hline \multirow{2}{*}{ II } & $2 \mathrm{mo}$ & 2.80 & 3.08 & 2.88 \\
& $7 \mathrm{mo}$ & 1.99 & 2.91 & 2.28 \\
\hline \multirow{2}{*}{ III } & $1.5 \mathrm{yr}$ & 0.22 & 0.37 & 0.25 \\
& $3 \mathrm{yr}$ & 0.09 & 0.09 & 0.09 \\
\hline \multirow{2}{*}{$\mathrm{IV}$} & $7 \mathrm{yr}$ & 0.05 & 0.26 & 0.10 \\
& $8 \mathrm{yr}$ & 0.05 & 0.24 & 0.08 \\
\hline \multirow{2}{*}{$\mathrm{V}$} & $13 \mathrm{yr}$ & 0.10 & 0.07 & 0.10 \\
& $13.5 \mathrm{yr}$ & 0.14 & 0.04 & 0.12 \\
\hline
\end{tabular}

B

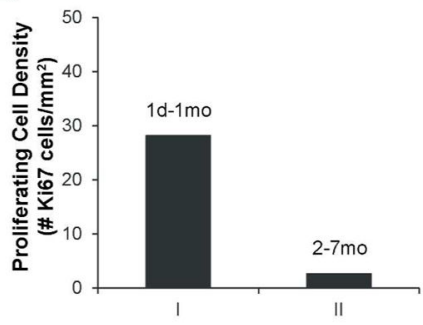

D

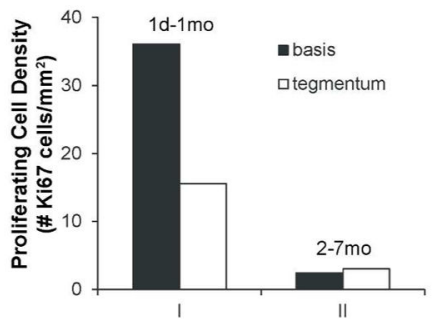

C

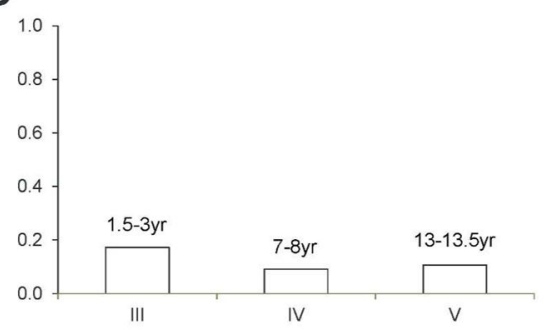

E

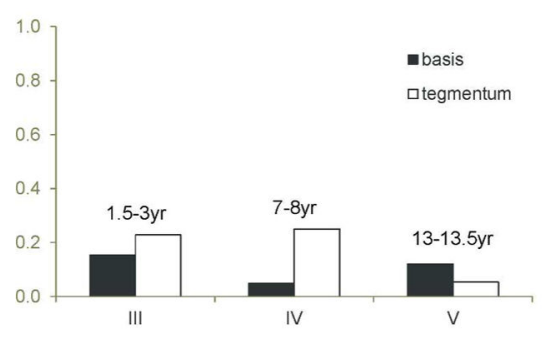

Figure 4. Temporal profile of pontine proliferation

A: Raw data for proliferating cell density (\#Ki67 ${ }^{+}$cells/area of interest $\left[\mathrm{mm}^{2}\right]$ ) for each pons specimen, expressed as the total and region-specific (basis, tegmentum) densities. Age Groups I-V refer to pooled data used for time-dependent analyses of proliferation density detailed in B, C, D, and E. B: Pons proliferation as a function of postnatal age, indicating a monophasic pattern of proliferation, with an approximately 10 -fold reduction between the first month of life (I) and 2-7 months of age (II). The proliferating cell density decreased significantly with increasing age (one-way ANOVA; $\mathrm{F}_{4,5}=49.77, \mathrm{p}<0.001$ ), and a significantly higher density of $\mathrm{Ki}^{+} 7^{+}$cells was observed in the 0-1 mo group (I, 28.1 cells $/ \mathrm{mm}^{2}$ ) compared to all other groups (Tukey post-hoc comparison; $\mathrm{p}<0.001$ ). C: Proliferation decreased to very low levels by $1.5-2$ years and remained very low throughout childhood (note second graph on right with reduced density scale on y-axis for time categories III-V). Note that a few $\mathrm{Ki} 67^{+}$cells are found in the pons in late childhood and adolescence. D-E: Compartmental analysis of proliferation as a function of time and location revealed decreased proliferation with increasing age and in the tegmentum relative to basis (two-way ANOVA; time: $\mathrm{F}_{4,10}=49.01, \mathrm{p}<0.001$; location: $\mathrm{F}_{1,10}=7.52, \mathrm{p}<0.05$; time*location: $\mathrm{F}_{4,10}=8.32, \mathrm{p}=0.003$ ). Proliferation was higher at $0-1 \mathrm{mo}$ (I) compared to all other timepoints (II-V) for both tegmentum $(\mathrm{p}<0.02)$ and basis $(\mathrm{p}<0.001)$ (Tukey post-hoc comparison). In addition, during the $0-1$ mo period (I) proliferation was higher in the basis 
relative to tegmentum $(\mathrm{p}<0.001)$. At later time points examined in the subregion analysis (II-V), proliferating cell density within and between the two pons regions was not statistically different. 


\begin{tabular}{|c|c|c|c|c|}
\cline { 2 - 5 } \multicolumn{1}{c|}{} & age & $\begin{array}{c}\text { basis } \\
\text { cells } / \mathrm{mm}^{2}\end{array}$ & $\begin{array}{c}\text { teg } \\
\text { cells } / \mathrm{mm}^{2}\end{array}$ & $\begin{array}{c}\text { total } \\
\text { cells } / \mathrm{mm}^{2}\end{array}$ \\
\hline \multirow{2}{*}{ I } & 1 day & 43.22 & 15.51 & 32.04 \\
& $1 \mathrm{mo}$ & 28.88 & 15.58 & 24.26 \\
\hline \multirow{2}{*}{ II } & $2 \mathrm{mo}$ & 2.80 & 3.08 & 2.88 \\
\cline { 2 - 5 } & $7 \mathrm{mo}$ & 1.99 & 2.91 & 2.28 \\
\hline \multirow{2}{*}{ III } & $1.5 \mathrm{yr}$ & 0.22 & 0.37 & 0.25 \\
\hline \multirow{2}{*}{ IV } & $3 \mathrm{yr}$ & 0.09 & 0.09 & 0.09 \\
\hline \multirow{2}{*}{ V } & $7 \mathrm{yr}$ & 0.05 & 0.26 & 0.10 \\
\hline & $8 \mathrm{yr}$ & 0.05 & 0.24 & 0.08 \\
\hline & $13 \mathrm{yr}$ & 0.10 & 0.07 & 0.10 \\
\hline
\end{tabular}



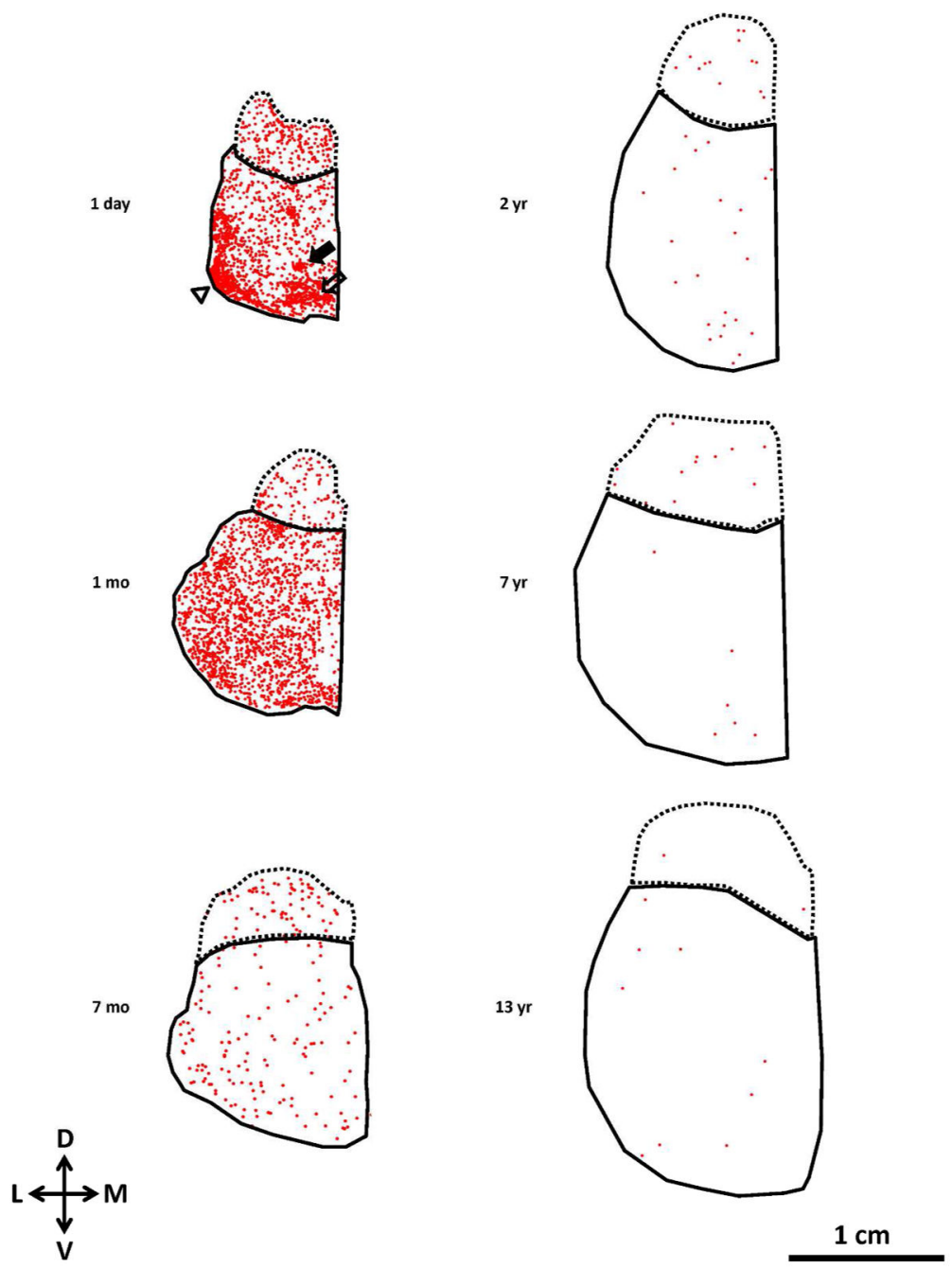

Figure 5. Regional profile of pontine cell proliferation

Mapping of Ki67+ cells within pons hemisections at different ages shows decreased proliferation levels over time and a transition from a ventrally-skewed distribution at 1 day to more homogeneous distributions at later timepoints. Note areas of increased density at 1 day corresponding to maturing white matter regions: middle cerebellar peduncle (open arrowhead), transverse pontocerebellar fibers (open arrow), and descending longitudinal corticospinal fiber tracts (solid arrow). $\mathrm{D}=$ dorsal, $\mathrm{V}=$ ventral, $\mathrm{M}=$ medial, $\mathrm{L}=$ lateral. Scale bar represents $1 \mathrm{~cm}$. 


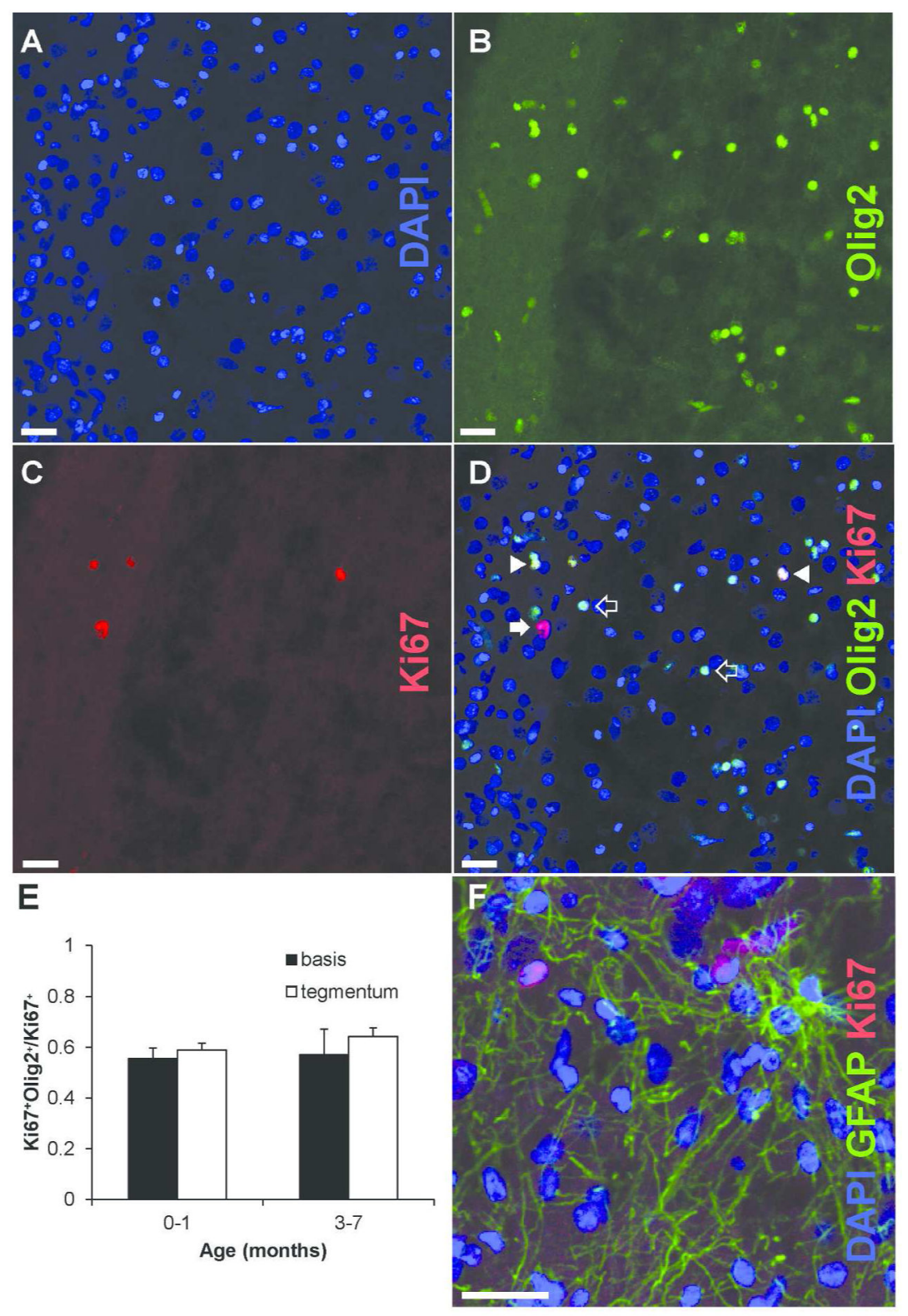

Figure 6. Olig2/Ki67 immunohistochemistry

Confocal microscopy of sections from 1 day old human mid-pons basis labeled with DAPI (A), Olig2 (B), Ki67 (C), and merged image (D) showing $\mathrm{Ki}^{+} / \mathrm{Olig} 2^{-}$(solid arrow), $\mathrm{Ki}^{-} 7^{-} / \mathrm{Olig} 2^{+}$(open arrow), and $\mathrm{Ki}^{+} 7^{+} / \mathrm{Olig} 2^{+}$(solid arrowhead) populations. E:

Comparison of the percentage of $\mathrm{Ki} 67^{+}$cells that were also Olig2 ${ }^{+}$revealed that more than half of proliferative cells are double-positive and these cells were distributed throughout the pons; no significant effect of age or location was observed (two-way ANOVA; time: $\mathrm{F}_{1.4}=$ $0.67, \mathrm{p}=0.46$; location $\mathrm{F}_{1,4}=1.61, \mathrm{p}=0.273$ ). $\mathbf{F}$ : Confocal microscopy of section from pontine basis in 1 month sample labeled for Ki67 (red), GFAP (green), and DAPI (blue) illustrating that proliferative cells are not reactive astrocytes and do not co-localize with GFAP. Scale bar $=20 \mu \mathrm{m}$. 


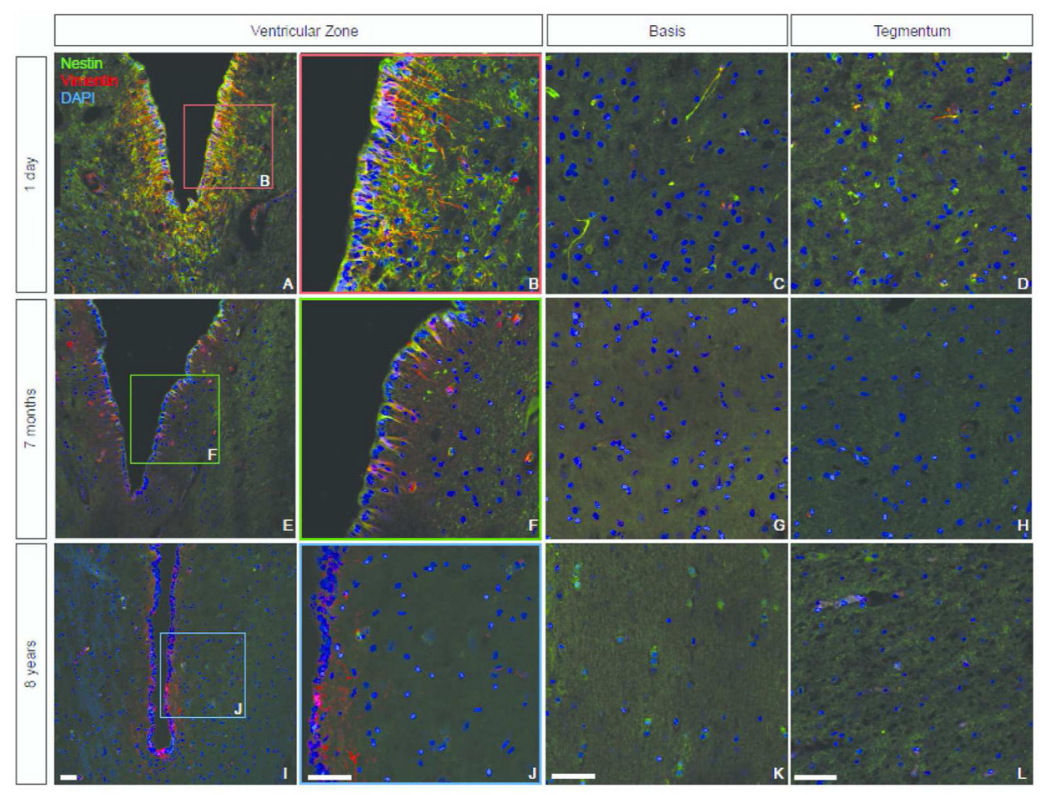

Figure 7. Nestin/Vimentin immunohistochemistry

Confocal images of three regions of the human pons labeled for nestin (green), vimentin (red), and DAPI (blue). A-D: At 1 postnatal day a dense population of vimentin ${ }^{+}$, nestin ${ }^{+}$, and vimentin ${ }^{+} /$nestin $^{+}$cells is observed in the ventricular zone of the dorsal pons. Within the tegmentum and basis, the few vimentin ${ }^{+} /$nestin $^{+}$processes were generally oriented parallel to white matter tracts. E-H: A markedly decreased VZ population of vimentin ${ }^{+} /$nestin $^{+}$cells can be identified in 7 mo samples. The vimentin ${ }^{+} /$nestin $^{+}$processes seen in the tegmentum and basis within the first month of life were no longer seen by 7 months of age. I-L: By 8 years of age the nestin ${ }^{+}$cells in the ventricular epithelium were no longer present, but a small subpopulation still expressed vimentin. Neither nestin ${ }^{+}$nor vimentin ${ }^{+}$cells were observed in 8 year old basis or tegmentum. Scale bars $=50 \mu \mathrm{m}$. 


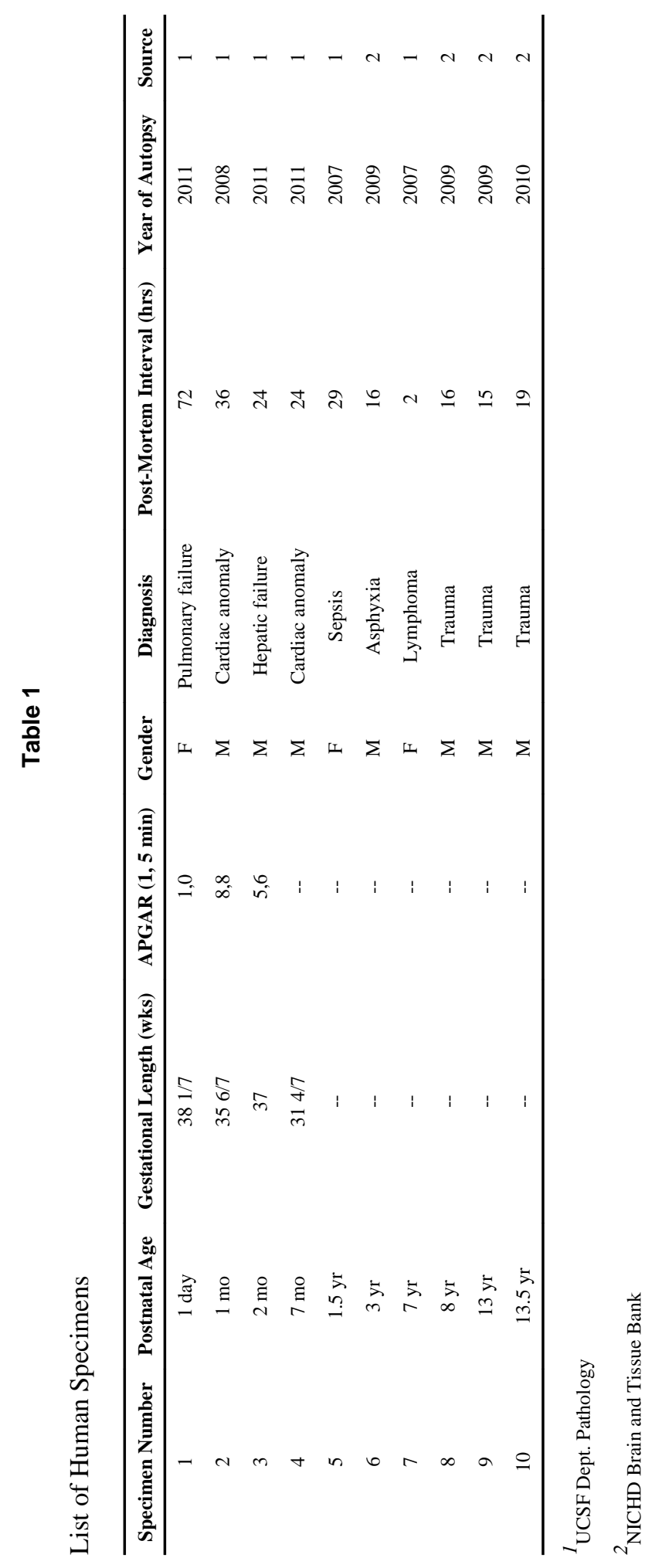

J Comp Neurol. Author manuscript; available in PMC 2016 February 15. 


\section{Table 2}

\section{Primary Antibodies Used}

\begin{tabular}{|c|c|c|c|c|}
\hline Antigen & Immunogen & Source, Species/Clonality, Catalog\#, RRID & Dilution & Tyramide Amplification \\
\hline GFAP & bovine full length protein & $\begin{array}{l}\text { Abcam, chicken polyclonal, cat\# ab4674, } \\
\text { RRID:AB_304558 }\end{array}$ & $1: 500$ & $\mathrm{~N}$ \\
\hline GFAP & $\begin{array}{l}\text { purified GFAP from porcine } \\
\text { spinal cord }\end{array}$ & $\begin{array}{l}\text { EMD Millipore, mouse monoclonal IgG } \text { Iglone GA5), }_{1} \text { cat\# MAB360, RRID:AB_2109815 }\end{array}$ & 1:1000 & $\mathrm{N}$ \\
\hline Ki67 & $\begin{array}{l}\text { Ki67 motif-containing cDNA } \\
\text { fragment }\end{array}$ & $\begin{array}{l}\text { Leica Microsystems, rabbit polyclonal, cat\# NCL- } \\
\text { Ki67p, RRID:AB_442102 }\end{array}$ & $1: 1000$ & $\mathrm{Y}$ \\
\hline Ki67 & human Ki67 & $\begin{array}{l}\text { BD Biosciences, mouse monoclonal } \operatorname{IgG}_{1 \kappa} \text { (clone B56), } \\
\text { cat\# 556003, RRID:AB_396287 }\end{array}$ & $1: 200$ & $\mathrm{Y}$ \\
\hline MBP & human myelin basic protein & $\begin{array}{l}\text { EMD Millipore, rabbit polyclonal, cat\# AB980, } \\
\text { RRID:AB_92396 }\end{array}$ & $1: 500$ & $\mathrm{~N}^{*}$ \\
\hline Nestin & human nestin cDNA fragment & $\begin{array}{l}\text { EMD Millipore, rabbit polyclonal, cat\# AB5922, } \\
\text { RRID:AB_91107 }\end{array}$ & $1: 500$ & $\mathrm{Y}$ \\
\hline Nestin & human nestin cDNA fragment & $\begin{array}{l}\text { Covance Research Products, mouse monoclonal } \operatorname{IgG}_{1} \\
\text { (clone 2C1 3B9), cat\# MMS-570P-100, } \\
\text { RRID:AB_291466 }\end{array}$ & $1: 500$ & $\mathrm{Y}$ \\
\hline Olig2 & $\begin{array}{l}\text { fusion protein containing } \mathrm{N}- \\
\text { terminus of mouse Olig2 }\end{array}$ & $\begin{array}{l}\text { CD Stiles/Harvard, rabbit polyclonal, cat\# DF308, } \\
\text { RRID: AB_2336877 }\end{array}$ & $1: 1000$ & $\mathrm{~N}$ \\
\hline Olig2 & $\begin{array}{l}\text { fusion protein containing } \mathrm{N}- \\
\text { terminus of mouse Olig2 }\end{array}$ & $\begin{array}{l}\text { CD Stiles/Harvard, mouse monoclonal IgG, cat\# } \\
\text { TV73-1C10, RRID: AB_2336878 }\end{array}$ & $1: 500$ & $\mathrm{Y}$ \\
\hline Vimentin & human thymic nuclear extract & $\begin{array}{l}\text { Sigma-Aldrich, mouse monoclonal IgM (clone LN-6), } \\
\text { cat\# V2258, RRID:AB_261856 }\end{array}$ & $1: 200$ & $\mathrm{~N}$ \\
\hline Vimentin & bovine eye lens protein & $\begin{array}{l}\text { Dako, mouse monoclonal } \operatorname{IgG}_{2 \mathrm{a}} \text { (clone Vim 3B4), cat\# } \\
\text { M7020, RRID:AB_2304493 }\end{array}$ & $1: 100$ & $\mathrm{Y}$ \\
\hline
\end{tabular}

* chromogenic DAB amplification 